Добавки для контура

набухания глин как правило, 1-3 \% KCl
Обеспечивают временную

или постоянную

совместимость глин с водой

Таким образом ГРП - это не просто метод интенсификации и увеличения притока нефти и нефтеотдачи, но и средство разработки месторождений. Известно, что важнейший показатель проектов на разработку месторождений - коэффициент извлечения нефти. Он редко бывает больше 35\%, как правило от 30 до 40 \% или в долях единицы - это 0,3 - 0,4.

Применение ГРП и вовлечение в разработку ранее не дренированных участков пластов позволяет на старых фондах скважин на несколько процентов поднять коэффициент извлечения нефти. Использование этого метода избавляет от необходимости забуривания дополнительных боковых стволов и скважин.

В отечественной практике имеется большой опыт по применению гидроразрыва.К примеру, на старых месторождениях ООО «РН-Юганскнефтегаза» таких как УстьБалыкское и Мамонтова применяя ГРП удалось увеличить текущую добычу, предотвратить падение и реанимировать старый фонд скважин. [6]

Список литературы:

1. Третьяк А.Я., Зиновьев В.В., Чихоткин В.Ф., Рыбальченко Ю.М., Чикин А.В. Методы увеличения нефтеотдачи пластов: Учеб. пособие / Юж.-Рос. гос. техн. ун-т. Новочеркасск: ЮРГТУ (НПИ), 2005. - 227 с.

2. Желтов Ю. П. Разработка нефтяных месторождений: Учебник для вузов - М.: Недра, 1986. 332 с.

3. Ремонт нефтяных и газовых скважин: учебное пособие / И. И. Кагарманов, А. Ю. Дмитриев. - М.: Изд-во ТПУ, 2007.

4. Инструкция по технологии глубокопроникающего гидравлического разрыва пласта. М., 1998. РМНТК - Нефтеотдача.

5. Справочная книга по текущему и капитальному ремонту скважин/ А.Д. Амиров, А.К. Карапетов, Ф.Д. Лемберанский. М.: Недра, 1979.

6. URL: http://neftegaz.ru (дата обращения: 24.02.2016 г.).

7. URL: http://www.neftepro.ru (дата обращения: 24.02.2016 г.)

\title{
Разработка нового вида огранки для муассанита
}

Корнилов П.В., студент, Северо-Восточный федеральный университет, 2. Якутск

E-mail: petr korn@mail.ru

Научный руководитель: к.т.н., доцент Федотова М.A.

Муассанит - новый вид ювелирного камня [1], который существует на рынке драгоценных камней около двадцати лет. Синтетический аналог и технический продукт, аналогичный по структуре и составу — карборунд (карбид кремния) [2]. 
Самым главным преимуществом муассанита перед другими ювелирными камнями являются показатель преломления и дисперсия, эти свойства определяют игру и блеск камня. Так как у муассанита показатель преломления (2,654-2,697) и дисперсия $(0,104)$ очень высокие [3], муассанит может играть даже при свете одной свечи в темной комнате. Не менее захватывающим фактором является история муассанита. Первый муассанит был найден в Каньоне Дьявола среди осколков метеорита [4]. Из этого можно сделать вывод, что муассанит является частичкой космоса, камнем, который в ограненном виде обладает отличной игрой и блеском. А так же синтезированный карбид кремния может иметь различные цвета и оттенки, что дает возможность экспериментировать, создавать новые виды огранок для определенных оттенков [5]. В связи с этим, целью работы является создание нового вида огранки для ювелирной вставки из муассанита.

Так как у муассанита показатель преломления и дисперсия выше чем у алмаза, бриллиантовая огранка КР-57 для муассанита, если оставить параметры такими же, не выявит полностью его «игру». В работе [6] авторы изменили некоторые параметры огранки, оставив количество граней таким же как у классической бриллиантовой огранки. Так, угол короны из 34,5 снижен до 28 градусов для муассанита. Для карбида кремния ювелирного качества могут подходить все виды огранки, только игра камня будет максимальной, если учитывать критический угол полуфабриката, который равен 22.2 градуса. Чем меньше критический угол отражения света в камне, тем больше будет игра света в нем [7]. Для примера, критический угол алмаза составляет 24.25 градуса [8]. Критический угол муассанита можно вычислить по формуле:

$$
\alpha=\operatorname{arcSin}(\sin 90 / n) \text {, }
$$

где n - показатель преломления.

Для того, чтобы «утечка» света стала минимальной, отношение углов павильона и короны должно соответствовать 68 градусам. Чтобы решить эту проблему, предлагаем сделать выпуклую площадку (15 градусов и 60 процентов), павильон с двойными основными и угловыми гранями (53 и 30 градусов), а так же с двойными парными клиньями основной и угловой гранях (50 и 80 процентов). Тем самым решается проблема с утечкой света, критическим углом и пропорциями полуфабриката. Благодаря тому, что вставка из муассанита будет иметь ступенчатую форму и двойные парные клинья, свет будет больше выходить со стороны короны, нежели с площадки, а благодаря 120 граням, он будет иметь отличную дисперсию. Таким образом, в результате проделанной работы предлагается обоснование для нового вида огранки ювелирной вставки из муассанита.

\section{Список литературы:}

1. Лучшие муассаниты в Москве и России! [электронный ресурс]/статья. электронные данные: URL:http://brightspark.ru

2. Муассанит. [электронный ресурс]/статья 2017 год. -электронные данные: URL:http://ru.wikipedia.org/wiki/Минерал

3. Муассанит. [электронный ресурс]/статья 2017 год. -электронные данные: URL:http://ru.wikipedia.org/wiki/Минерал

4. Муассанит - самый блестящий драгоценный камень на земле. [электронный pecypc]/статья 2016 год. -электронные данные: URL:http://crystalit.ru/muassanit-samyyblestyashchiy-dragocennyy-kamen-na-zemle 
5. Муассанит. [электронный ресурс]/статья. -электронные данные: URL:http://www.silver-lines.ru/silver/info/stone/v?id=1697384

6. Hines E., Nassau K. Cut: It's Relevance and Importance As It Pertains to a Jewel's Optical Physics. - Charles\&Colvard Created Moissanite, 2005. - 12 p.

7. Бриллиант брильянт алмаз огранка. [электронный ресурс]/статья. -электронные данные: URL:http://laser-portal.ru/content_142

8. Бриллиант брильянт алмаз огранка. [электронный ресурс]/статья. -электронные данные: URL:http://laser-portal.ru/content_142

\section{Малоизвестное разрушительное землетрясение в Мраморном море 10.VII.1894 г.: уточнение параметров по макросейсмическим данным}

Королева А.О., студентка,
МГРИ РГГРУ, г. Москва

E-mail: nikonov@ifz.ru

Научный руководитель:

д.2-м.н. Никонов А.A.

В пределах Средиземноморского сейсмического пояса территория северозападной Турции (провинции Фракия и Вифиния) и окрестности Босфорского пролива сейсмически малоактивны, во всяком случае, по сравнению с Малой Азией и бассейном Эгейского моря. На указанном участке землетрясения возникают редко, а сильные, если и фиксировались, то единично [1]. В этих условиях каждое сильное землетрясение представляет специальный интерес и требует особого рассмотрения. Разрушительное землетрясение 10.VII.1894 г. отражено в каталогах, однако, без указания пределов возможных отклонений, с неполным набором основных параметров, и с различиями в их значениях у разных авторов (табл. 1). Эта ситуация, а также отсутствие важных сведений в поздних сводках, побудили авторов обратиться к первоисточникам, включая и русские, и заново и комплексно обработать сведения из них с целью уточнения очаговых параметров.

Таблица 1

Основные параметры землетрясения 10. VII. 1894 по данным разных авторов

\begin{tabular}{|l|l|l|l|l|l|l|r|}
\hline Дата & Время & \multicolumn{2}{l|}{$\begin{array}{l}\text { Координаты, } \varphi^{\circ}{ }_{\mathrm{N}} ; \\
\lambda_{\mathrm{E}}^{\circ}\end{array}$} & $\mathrm{M}$ & $\mathrm{h}$, км & $\mathrm{I}_{0}$ & Источник \\
\hline 10.07 .1894 & $12: 30$ & 40.8 & 29.0 & & & $\mathrm{X}$ & {$[2]$} \\
\hline 10.07 .1894 & & 40.6 & 28.7 & 6.7 & & & {$[3]$} \\
\hline 10.07 .1894 & $18: 33$ & 40.8 & 29.1 & $(6.7)$ & $\mathrm{H}$ & $(\mathrm{IX})$ & {$[4]$} \\
\hline 10.07 .1894 & $12: 33$ & 40.6 & 28.7 & & $\mathrm{H}$ & $\mathrm{IX}$ & {$[5]$} \\
\hline 10.07 .1894 & $12: 30$ & $\begin{array}{l}40.8 \pm \\
0.1\end{array}$ & $29.0 \pm 0.2$ & $6.5 \pm 0.2$ & $\begin{array}{l}13(3- \\
25)\end{array}$ & IX \pm 0.5 & $\begin{array}{l}\text { По } \\
\text { авторам }\end{array}$ \\
\hline
\end{tabular}

В настоящем сообщении отражена только часть исследования, включающая разные группы макросейсмических проявлений, на суше и в море, вблизи эпицентра у северо-восточного побережья Мраморного моря. Значимость выявления и обработки на современном уровне надежных первичных сведений о разрушительном землетрясении 